\section{THU0586 ESTABLISHING THE KEY COMPONENTS OF A EULAR PORTFOLIO FOR TRAINING IN RHEUMATOLOGY: A EULAR SCHOOL OF RHEUMATOLOGY INITIATIVE}

M. Van Onna ${ }^{1}$, S. Ramiro ${ }^{2}$, C. Haines ${ }^{3}$, M. Holland-Fischer ${ }^{4}$, J. A. P. Da Silva ${ }^{5}$, J. Dudler ${ }^{6}$, C. Edwards ${ }^{7}$, A. Alunno ${ }^{8}$, E. Nikiphorou ${ }^{9}$, L. Falzon ${ }^{10}$, F. Sivera ${ }^{11}$ on behalf of Working group on Development of a EULAR Portfolio of Rheumatology.. ${ }^{1}$ MUMC Maastricht, Netherlands; ${ }^{2}$ LUMC, Leiden, Netherlands; ${ }^{3}$ University of Nottingham, Nottingham, United Kingdom; ${ }^{4}$ Aalborg University Hospital, Aalborg, Denmark; ${ }^{5}$ Faculty of Medicine and University Hospital, Coimbra, Portugal; ${ }^{6}$ Fribourg Hospital Cantonal, Fribourg, Switzerland; ${ }^{7}$ University Hospital Southampton, Southampton, United Kingdom; ${ }^{8}$ University of Perugia, Perugia, Italy; ${ }^{9}$ King's College London, London, United Kingdom; ${ }^{10}$ Feinstein Institutes for Medical Research, New York, United States of America; ${ }^{11}$ Hospital Gral Univ Elda, Elda, Spain

Background: In clinical training, a portfolio is expected to stimulate learning and encourage critical reflection. Some, but not all, European countries use a portfolio in rheumatology training, and their scope varies widely. A EULAR portfolio for Rheumatology trainees could contribute to improve overall training, raise educational standards, foster the setting of common goals and harmonize rheumatology training across countries.

Objectives: Develop key components that should be included in a EULAR portfolio of Rheumatology.

Methods: A working group (WG) composed of 9 rheumatologists and 1 educationalist was established. A systematic literature review (SLR) was conducted in November 2018, according to the PIM structure: Population: trainees; Instrument of interest: portfolio; Measurement of properties of interest: content portfolio. A survey was disseminated among the WG group and WG members of the EMerging EUlar NETwork (EMEUNET), inquiring about the content and structure of existing national portfolios. Portfolio materials of selected countries were reviewed. Last, the WG elected the key components of the portfolio.

Results: 13/2,034 articles were included in the SLR (12 high/1 moderate risk of bias). Information on direct observation of procedural skills (DOPS) $(9 / 13)$, personal reflections $(8 / 13)$, learning goals $(5 / 13)$ and multisource feedback $(5 / 13)$ were most often included in the portfolio. Twenty-five respondents filled out the survey (response rate $\approx 50 \%$ ). Reflective writing $(n=7)$, learning goals $(n=4)$ and feedback $(n=4)$ were considered the most useful components of a portfolio. About half indicated that a portfolio was a bureaucratic burden; 4 respondents mentioned lack of feedback by supervisors as a barrier. Portfolio materials of 7 European countries were reviewed. Several portfolios (Germany, Italy, Greece and Spain) were logbooks, i.e. a record of clinical activities. Other portfolios (UK, Denmark, The Netherlands) also included information on workplace-based assessments, learning goals, and personal reflections. The proposed key components of the portfolio are included in Table 1.

Table 1. Key components of the EULAR portfolio of Rheumatology.

\begin{tabular}{|c|c|}
\hline Key component & Content \\
\hline Curriculum vitae & $\begin{array}{l}\text { Personal record of achievements, experiences, knowl- } \\
\text { edge and skills }\end{array}$ \\
\hline Personal Development Plan & Learning goals and action plan \\
\hline \multirow[t]{4}{*}{ Clinical work } & $\begin{array}{l}\text { Information on managing patients (e.g. rheumatoid } \\
\text { arthritis) }\end{array}$ \\
\hline & Skills (e.g. joint aspiration) \\
\hline & Assessments (summative and formative) \\
\hline & Personal reflections \\
\hline \multirow[t]{2}{*}{ Professional behaviour } & Multisource feedback \\
\hline & Personal reflections \\
\hline \multirow[t]{3}{*}{ Education } & $\begin{array}{l}\text { Continuing professional development, list of formal and } \\
\text { non-formal learning activities }\end{array}$ \\
\hline & $\begin{array}{l}\text { Assessments (e.g. teaching assessment, evidence } \\
\text { based medicine assignment) }\end{array}$ \\
\hline & Personal reflections \\
\hline \multirow[t]{2}{*}{ Research } & List of abstracts, published articles \\
\hline & $\begin{array}{l}\text { Information on research funding, scholarships, bursaries, } \\
\text { academic posts }\end{array}$ \\
\hline
\end{tabular}

Conclusion: This initiative resulted in the establishment of a list of key components to be included in a EULAR portfolio of Rheumatology. Assessment forms for each key portfolio component are currently being developed. Portfolio implementation, particularly in countries that do not use it yet, may contribute significantly to promote a higher standard of patient care across Europe.

Disclosure of Interests: Marloes van Onna: None declared, Sofia Ramiro Grant/ research support from: MSD, Consultant of: Abbvie, Lilly, Novartis, Sanofi Genzyme, Speakers bureau: Lilly, MSD, Novartis, Catherine Haines: None declared, M. Holland-Fischer: None declared, José Antonio P. da Silva Grant/research support from: Pfizer, Abbvie, Consultant of: Pfizer, AbbVie, Roche, Lilly, Novartis, Jean Dudler: None declared, Christopher Edwards Grant/research support from: Abbvie, Biogen, Roche, Consultant of: Abbvie, Samsung, Speakers bureau:
Abbvie, BMS, Biogen, Celgene, Fresenius, Gilead, Janssen, Lilly, Mundipharma, Pfizer, MSD, Novartis, Roche, Samsung, Sanofi, UCB,

Alessia Alunno: None declared, Elena Nikiphorou: None declared, L. Falzon: None declared, Francisca Sivera: None declared

DOI: 10.1136/annrheumdis-2020-eular.1477

\section{IHURSDAY, 04 JUNE 2020}

\section{Educational cases}

\section{THU0587 TB OR NOT TB? THIS IS THE QUESTION. CASE REPORT OF AN EXTRAPULMONARY TUBERCULOUS ARTHRITIS.}

N. Abaza ${ }^{1}{ }^{1}$ Faculty of Medicine - Ain Shams University - Cairo - Egypt., Rheumatology and Rehabilitation, Cairo, Egypt

Background: Tuberculous (TB) arthritis consists of $1-3 \%$ of all TB cases, whereas TB tenosynovitis \& bursitis account for $1 \%$. Primarily it involves large joints but occasionally smaller non-weight-bearing joints. Diagnosis is usually delayed due to lack of awareness, radiographic findings \& constitutional or pulmonary involvement.

Objectives: We aim to increase rheumatologists awareness to detect possible TB etiology for arthritis \& tenosynovitis.

Methods: Our case is a 32 years old male complaining of polyarthritis of wrists MCPs, ankle joints 4 months prior to presentation. Patient was referred as diagnosed rheumatoid patient resistant to treatment based on clinical presentation \& laboratory investigation. His lab. was as follows; ESR $76 \mathrm{~mm} / \mathrm{hr}$, CRP $56.6 \mathrm{mg} / \mathrm{L}$, RF $181.8 \mathrm{IU} / \mathrm{ml}$, Serum creat $0.8 \mathrm{mg} / \mathrm{dL}$, SGOT $20 \mathrm{SGPT} 22$, FBS 94, Uric acid 5.4, Hepatitis \& HIV negative. CBC showing Hb $14.1 \mathrm{~g} / \mathrm{dL}$, TLC 7030/m \& platelets $289000 / \mathrm{ml}$. There was no history of genitourinary, gastrointestinal manifestations, oral/genital ulcers, ophthalmological, mucocutaneous, cardiac pulmonary, hepatic nor renal manifestations. The treatment at time of presentation was Methotrexare $25 \mathrm{mg} /$ week IM injection, Leflunamide $20 \mathrm{mg} / \mathrm{d}$ \& low dose steroids, prednisolone $5 \mathrm{mg} / \mathrm{d}$. Patient was referred to our department to assess activity, perform musculoskeletal ultrasound to the various involved joints. Hence, expected by referring physician to shift from DMARDs to biologic treatment.

Results: MSUS study following eular guidlines showed active synovitis in both radiocarpal \& midcarpal joints bilaterally grade II by doppler signal (figure 1). Other active synovitis in multiple MCPs as well as tenosynovitis of Peroneus longus and brevis bilaterally was detected (figure 1). The swelling aound the ankle was alarming though the other swollen joints seemed to be consistent with a case of RA in activity. This swelling revealed a well-defined hypoechoic heterogeneous cystic fluid collection with posterior through-transmission (figure 2) \& hyperechoic hyperemic wall on PD imaging opposite medial malleolous of right fibula. The laboratory investigations prior to shifting patient had to included TB tests, tuberculin test and PCR following the positive result that we found in the skin test. Aspiration was performed from the cystic swelling and sent for clinical pathology analysis. Thick yellowish fluid aspirate on cytology revealed moderately cellular mainly of PMN cells, neutrophils, nuclear debris in proteinaceous background no atypical or malignant cells were found. As regards bacteriology no pus with no growth (both aerobic \& anerobic). These results warranted us to perform a culture for atypical bacteria and revealed growth of mycobacterium tuberculosis. AntiTB therapy was started for 9 months in the form of 2 months of isoniazid (INH) and rifampicin (RIF), pyrazinamide (PZA) and ethambutol (EMB) followed by 7 months of INH and RIF. Excision of the synovial cyst was done on the spot.

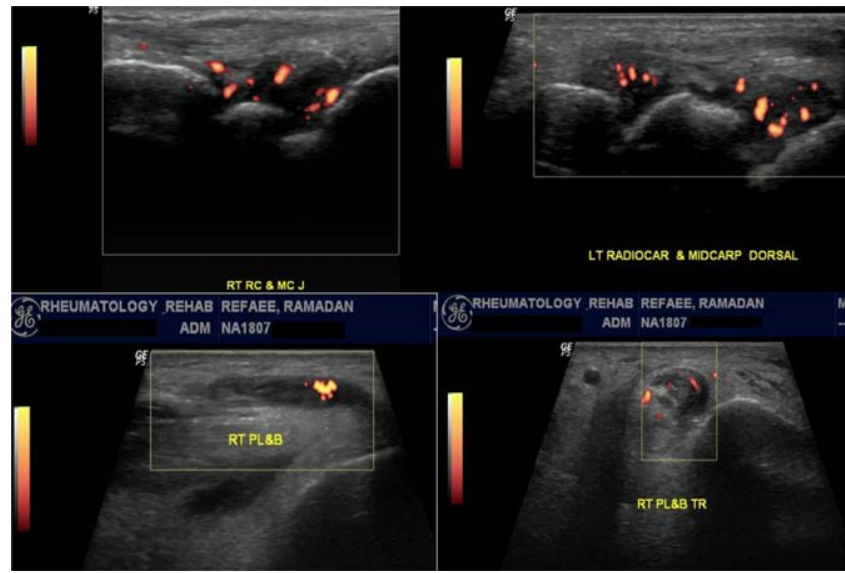

Figure 1. 